\title{
Impact of Transfer Pricing for Special Tax Adjustment Measures on Corporate Effective Tax Rate in China
}

\author{
Jui-Chih Wang*, Yu-Shan Chen \\ ${ }^{1}$ National Taipei University of Business, Department of Accounting Information, Taiwan \\ ${ }^{2}$ Auditor, Deloitte \& Touche, National Taipei University of Business, Department of Accounting Information, Taiwan \\ Email: ${ }^{\star}$ jcwang@ntub.edu.tw
}

How to cite this paper: Wang, J.-C., \& Chen, Y.-S. (2020). Impact of Transfer Pricing for Special Tax Adjustment Measures on Corporate Effective Tax Rate in China. Chinese Studies, 9, 1-13. https://doi.org/10.4236/chnstd.2020.91001

Received: November 27, 2019

Accepted: January 3, 2020

Published: January 6, 2020

Copyright $\odot 2020$ by author(s) and Scientific Research Publishing Inc. This work is licensed under the Creative Commons Attribution International License (CC BY 4.0).

http://creativecommons.org/licenses/by/4.0/ (c) (i) Open Access

\begin{abstract}
Corporate tax avoidance activities are prevalent in many countries, some of which have formulated anti-tax avoidance policies to curb such activities. China amended the chapter on special tax adjustment in the Enterprise Income Tax Law in 2008 and implemented Measures for Special Tax Adjustment in 2009. This study applies the Shanghai and Shenzhen A-share securities markets in 2005-2015 to investigate whether the implementation of Measures for Special Tax Adjustment has effectively curbed corporate tax avoidance activities and increased income tax costs. The empirical results indicate that company effective tax rates (ETRs) are increased significantly after the implementation of Measures for Special Tax Adjustment. And, companies with greater amounts of goods (or service) related party transactions significantly increased ETRs after the implementation of Measures for Special Tax Adjustment. The Chinese government continues to issue numerous rules focused on transfer pricing to amend Measures for Special Tax Adjustment. Therefore, we recommend that corporations carefully assess relevant transactions to avoid being subject to Measures for Special Tax Adjustment legislation.
\end{abstract}

\section{Keywords}

Anti-Tax Avoidance Policies, Special Tax Adjustment Measures, Transfer Pricing, Effective Tax Rate

\section{Introduction}

In this era of globalization, enterprises seek means of reducing their global tax burden to increase global profit in order to gain a foothold in the global economy. Because tax law differences amongst countries, enterprises can engage in tax 
avoidance strategies (e.g., practice irregular transfer pricing, engage in thin capitalization, create a controlled foreign corporation, and abuse double tax treaties) by exploiting these differences.

For tax fairness and avoid erosion of tax revenue, in recent years, many countries have set up relevant regulations to regulate the enterprises tax avoidance, such as the UK and India, are considering the enactment of a General Anti-Avoidance Rule (GAAR). A GAAR is typically a statutory rule that empowers a revenue authority to deny taxpayers the benefit of an arrangement that they have entered into for an impermissible tax-related purpose. China's State Administration of Taxation (hereinafter referred to as the "SAT") amended the People's Republic of China Enterprise Income Tax Law in 2008 (hereinafter referred to as the "Enterprises Income Tax Law") to regulate multinational companies the possibility of tax avoidance behaviors and promulgated the Implementation Measures for Special Tax Adjustment (Trial), Document No. 2 (2009) (hereinafter referred to as the "Measures for Special Tax Adjustment") to regulate and strengthen the management of special tax adjustment.

Measures for Special Tax Adjustment is China's main transfer pricing guidance that contains detailed rules in areas such as transfer pricing adjustments, cost sharing arrangements (CSAs), controlled foreign companies (CFCs), thin capitalization (TC), the general anti-avoidance rule (GAAR), etc. The Measures for Special Tax Adjustment also incorporates a number of recommendations of the OECD in the context of the base erosion and profit shifting (BEPS) initiative, but does so taking into account China's unique economic environment and factors relevant.

This study investigates whether corporate effective tax rates (ETRs) will increase after the implementation of China's Measures for Special Tax Adjustment and the interaction effects with goods (or service) transactions, inter-financing transactions, and investment income transactions within the related parties. We use the A-share listed companies in Shanghai and Shenzhen from 2005 to 2015 to investigate whether the implementation of the 2009 Measures for Special Tax Adjustment has effectively curbed corporate tax avoidance activities and increased corporate income tax costs. The empirical results indicate that the ETRs of companies increase significantly after the implementation of the Measures for Special Tax Adjustment. Additionally, the ETRs of companies with a greater number of related party transactions of goods (or services) significantly increase after the implementation of Measures for Special Tax Adjustment.

The primary contribution of this study is that our results support the effectiveness of China's Measures for Special Tax Adjustments and suggest that enterprises should carefully assess their related party transactions to avoid the risk of tax adjustment. In addition, in contrast to the related literature on the effect of a single tax policy on tax avoidance, this study investigates, simultaneously, the effect of three regulations from Measures for Special Tax Adjustment on corporate tax burden, including transfer pricing (TP), thin capitalization (TC), and controlled foreign corporation (CFC) rules.

The rest of this paper is organized as follows: Section 2 reviews the related li- 
terature on the introduction of China's anti-tax avoidance and special tax adjustment rules, and deduces the effect of their enactment on ETRs; we develop the research hypotheses accordingly. Section 3 outlines our empirical model and sample selection. The empirical results are shown and discussed in Section 4, and Section 5 provides some concluding remarks.

\section{Literature Review and Hypotheses Development}

\subsection{Background of Global Anti-Tax Avoidance Rules}

Tax avoidance is the legal usage of the tax regime in a single territory to one's own advantage to reduce the amount of tax that is payable by means that are within the law. Laws known as a General Anti-Avoidance Rule (GAAR) statutes which prohibit "tax aggressive" avoidance have been passed in several developed countries including Canada, Australia, New Zealand, South Africa, Norway, Hong Kong and the United Kingdom which included specific anti-tax avoidance rules in order to counteract tax-planning strategies. Transfer pricing rules, thin-capitalization rules and controlled foreign company rules seem to be particularly important policies. Countries using TP, TC or CFC rules have significantly increased.

Although three rules pursue a similar goal, they differ significantly in scope and application. The OECD TP rules for multinational enterprises and tax administrations provide guidance on the application of the "arm's length principle", which is the cross-border transactions between associated enterprises for tax purpose. TC rules are set up by the host countries of the borrowing affiliates and restrict the tax deductibility of interest payments. Thus, these two rules directly restrict the earnings stripping opportunities of entities located in such countries. By contrast, CFC rules do not directly focus on the profit-shifting strategies of affiliates located in the jurisdiction implementing the rule. The CFC rules restrict tax-planning opportunities of sub-level controlled affiliates which are located in foreign countries. From the parent firm's point of view, CFC rules are part of the home-country tax legislation, whereas in the case of TC rules, the tax law of the host countries defines whether interest deduction is denied or not.

\subsection{Anti-Tax Avoidance Rules in China}

On 2 December 2014 the Chinese SAT released the GAAR Measures, these measures define the ambit of tax avoidance schemes and set out in detail the tax authority procedures to be followed for GAAR case selection, examination and conclusion. The GAAR Measures intend to provide a basis for more transparent and consistent application of the GAAR, going forward, and are part of a suite of new regulations for the enforcement of China's international tax rules. The GAAR Measures could have a significant impact on tax enforcement of international tax arrangements in China going forward.

The GAAR Measures explain that the main purpose of the tax-avoidance arrangement is to obtain a tax benefit. The arrangement takes a form permissible under tax rules, but which is not consistent with its underlying economic sub- 
stance. Transfer pricing, cost sharing arrangement, controlled foreign company and thin capitalization provisions are to be applied in precedence over the GAAR. In making tax adjustments, tax authorities must consider the tax effects of the scheme if its form had followed its economic substance.

On January 8, 2009, the SAT issued the Implementation Measures for Special Tax Adjustments (Trial), Document No. 2 (2009) Rules. Measures for Special Tax Adjustment is China's main transfer pricing guidance that contains detailed rules in areas such as transfer pricing adjustments, cost sharing arrangements, controlled foreign companies, thin capitalization, the general anti-avoidance rule, etc. The Measures for Special Tax Adjustment also incorporates a number of recommendations of the OECD in the context of the base erosion and profit shifting (BEPS) initiative, but does so taking into account China's unique economic environment and factors relevant. The Measures for Special Tax Adjustment also includes new chapters addressing intangible assets, intragroup services transactions and profit level monitoring.

The Measures for Special Tax Adjustment provide detailed requirements for contemporaneous documentation on related party transactions. The documents required mainly include the following: organizational structure, business operations, information concerning related party transactions, comparability analysis, selection and application of transfer pricing methods. The Measures for Special Tax Adjustment provide the procedures and requirements of transfer pricing investigations conducted by the tax authorities.

Under the Measures for Special Tax Adjustment, the tax authorities may, during a transfer pricing audit, request that the audited enterprise, related parties, and other parties that are relevant to the related party transactions provide information. If the tax authorities make a tax adjustment as a result of a transfer pricing audit, the enterprise will be placed on the watch list for five years following the last adjustment year. The tax authorities will assess the changes of business and related party transactions based on this document, and then request the enterprise to make self-adjustment.

Liu \& Liu (2011) show that Measures for Special Tax Adjustment are an effective deterrent against corporate tax avoidance. Accordingly, our first hypothesis asserts that the implementation of Measures for Special Tax Adjustment effectively prevents Chinese enterprises from engaging in tax avoidance, resulting in an increase in the corporate ETRs:

H1: Ceteris paribus, the implementation of Measures for Special Tax Adjustment of China in 2009 will effectively curb corporate tax avoidance behavior, thereby increasing the ETRs.

\subsection{Transfer Pricing Rules in China}

In China, articles relevant to transfer pricing are found mainly in Chapter 6 "Measures for Special Tax Adjustment" of Enterprise Income Tax Law. The corporate income tax law provides the arm's-length principle as the guiding 
principle for related party transactions and empowers the tax authorities in China to adjust a taxpayer's taxable income if it fails to comply with the arm's-length principle in its dealings with related parties. Following the issuance of a set of revamped transfer pricing regulations in 2009, the SAT issued many transfer pricing related regulations and rules addressing issues such as contemporaneous documentation administration, intra-group services transactions, license royalty treatment and single-function entities.

Jacob (1996) finds that US-based MNEs shift income between geographic locations in response to changes in tax rates and rules. The volume of intra-firm international transfers appears to suggest that transfer prices are the mechanism for income shifting. Oyelere \& Emmanuel (1998) compare the differences between UK-based foreign-controlled enterprises and UK-controlled enterprises, and find that despite having similar capability, the foreign-controlled enterprises will use the intra-firm international transfer pricing to reduce the profitability and manipulate earnings by increasing the ratio of dividend payouts.

Clausing (2003), Bartelsman \& Beetsma (2003) find that companies engaged in transfer pricing or income shifting by using the differences of income taxes between USA and OECD. Clausing (2006), Bernard, Jensen, \& Schott (2009), Olibe \& Rezaee (2008) find that firms' globle tax burdens are negatively associated with their intra-firm transactions. Park, Park, Sun, \& Woo (2016) examine whether multinational companies carry out tax avoidance through subsidiaries. Their results show that MNCs use overseas transfer pricing behaviors to avoid tax actively when compared to firms without overseas subsidiaries.

Through their TP behaviors, MNEs will transfer their taxes to other countries, resulting in loss of tax revenue in their domestic country (Gramlich \& Wheeler, 2003; Oyelere \& Emmanuel, 1998). Therefore, most governments enacted TP rules to regulate irregular TP behaviors of firms. Accordingly, this study concludes that the implementation of Measures for Special Tax Adjustment will suppress the related parties' irregular TP activities and then increase their ETRs. Therefore, we propose the following hypothesis:

H2: Ceteris paribus, after the implementation of Measures for Special Tax Adjustment in 2009, the ETRs will increase more for companies with greater amounts of related party transactions of goods (or services).

\section{Empirical Model and Data}

\subsection{Empirical Model}

This study focuses on the effects of the implementation of the Special Tax Adjustment Measures in China, as well as on whether the implementation of the transfer pricing rules could increase corporate income tax costs, thereby increasing the ETRs of enterprises. We establish the following regression models ${ }^{1}$ :

\footnotetext{
${ }^{1}$ This study deletes three main variables, namely OPER, FINANCE, and INVEST, due to high correlation coefficients between these three original variables and their interaction variables $(\mathrm{DY} 09 \times$ OPER, DY09 $\times$ FINANCE, DY09 $\times$ INVEST). The high variance inflation factors of these variables imply the problem of multicollinearity.
} 


$$
\begin{aligned}
\operatorname{ETR}_{i, t}= & \alpha_{0}+\alpha_{1} \mathrm{DYO9}_{i, t}+\alpha_{2} \mathrm{DYO9}_{i, t} \times O P E R_{i, t}+\alpha_{3} \mathrm{SIZE}_{i, t}+\alpha_{4} \mathrm{ROA}_{i, t} \\
& +\alpha_{5} L E V_{i, t}+\alpha_{6} P P E_{i, t}+\alpha_{7} \mathrm{TECH}_{i, t}+\alpha_{8} L_{-} E T R_{i, t}+\varepsilon_{i, t}
\end{aligned}
$$

$E T R$ is the effective tax rate; $D Y 09$ is the dummy variable of Measures for Special Tax Adjustment period; OPER is the related parties' goods (service) transaction ratio; $S I Z E$ is the size of enterprise; $R O A$ is the profitability; $L E V$ is the leverage of finance; $P P E$ is the capital intensity; $T E C H$ is the dummy variable of high-tech enterprises; $L \_E T R$ is the pre-period effective tax rate.

\subsection{Variables Measurement}

\subsubsection{Dependent Variable}

Effective tax rates $(E T R)$ :

Effective tax rates (ETR) reflect the income tax costs, measured by current income tax expense divided by the pre-tax income for the current period (Siegfried, 1974; Gupta \& Newberry, 1997; Chen, 2003; Desai \& Dharmapala, 2006; Tang et al., 2017)².

\subsubsection{Hypothesis Variables}

Measures for Special Tax Adjustment implementation period (DY09): This study investigates whether the implementation of Measures for Special Tax Adjustment has effectively increased corporate income tax costs since 2009. DY09 is the year dummy variable, which equals 1 if a firm-year observation relates to the post-implementation year of Measures for Special Tax Adjustment (2009 to 2015); else $D Y 09=0$. We expect the coefficient on $D Y 09$ to be positive.

The related parties' goods or service transaction ratio (OPER): $\mathrm{H} 2$ extends prior approaches by explicitly exploring whether companies with greater amounts of related party goods (or service) transactions will increase their ETRs after the implementation of Measures for Special Tax Adjustment.

Jacob (1996) and Park et al. (2016) examine whether multinational companies carry out tax avoidance through subsidiaries. Their results show that these firms actively avoid taxes using overseas TP behaviors, compared with companies without overseas subsidiaries. Following the procedures of Park et al. (2016), this study uses the related parties' goods (or service) transaction amounts divided by total assets to measure the level of TP from related affiliates. We expect a positive relationship between the ETR and the interaction of $D Y 09^{*} O P E R$.

\subsubsection{Control Variables}

The firm size (SIZE): Large companies can establish superior taxation strategies due to economies of scale while also facing a greater risk of being exposed to various regulations; this raises the political cost hypothesis, which states that large firms are more inclined to prefer tax smoothing rather than aggressive tax avoidance strategies (Chen, 2003; Zimmerman, 1983). Comparatively, the political power hypothesis favors big businesses with more resources for lobbying the government and tax planning to reduce taxes; therefore, their ETRs will be lower ${ }^{2}$ If companies with negative current income tax expense or pre-tax income, then their effective tax rates are set to zero. 
(Porcano, 1986; Siegfried, 1974). Accordingly, we make no prediction as to the sign of its coefficient.

The profitability (ROA): Gupta \& Newberry (1997) indicate that companies with a larger profit have a higher tax burden (Chen, Lin, \& Chang, 2001; Liu, Lin, \& Huang, 2001). However, an enterprise with higher profitability may have more resources for tax planning (Rego, 2003). Therefore, we also make no prediction as to the sign of this coefficient.

Financial leverage ( $L E V$ ): Due to the tax shield effect of debt interest expenses, debt financing will reduce ETRs (Graham, 2000; Mills, Erickson, \& Maydew, 1998; Stickney \& McGee, 1982). This study thus expects a negative relationship between LEV and ETR.

Capital intensity (PPE): Companies with a high ratio of depreciable operating assets can use a tax shield to lower their tax burden (Gupta \& Newberry, 1997; Stickney \& McGee, 1982). Therefore, we also expect a negative relationship between PPE and ETR.

New and high-tech enterprises (TECH): The Chinese government allows new and high-tech enterprises to apply the preferential corporate income tax rate of 15\%. Therefore, this study sets a dummy variable for which TECH equals 1 if enterprises belong to new and high-tech enterprises; otherwise, it is equal to 0 . The ETR is expected to be negatively associated with the variable of $T E C H$.

Pre-period effective tax rate $\left(L \_E T R\right)$ : To avoid the current ETR being influenced by the pre-period ETR, this study controls the $L_{-} E T R$ and expects it to be positively associated with the ETR.

\subsection{Data Sources and Sample Selection Process}

The sample of this study comprises A-share listed companies in Shanghai and Shenzhen of China from 2005 to 2015. Since the new Enterprises Income Tax Law was implemented on January $1^{\text {st }}, 2008$, we exclude all the data for 2008 from our analysis to avoid potential confounding effects. As a result, the pre-implementation period ranges from 2005 to 2007 while the post-implementation period ranges from 2009 to 2015 .

All of the financial data are derived from the GTA database (CSMAR Solution), and total firm-year observations are 22,195. During the sample selection process, we exclude observations of the finance and insurance industry and firms with insufficient financial statement data or missing variables. Additionally, to avoid the influence of extreme values, we exclude the outliers at the $1 \%$ and $99 \%$ levels. Thus, a total of 16,848 firm-year observations are obtained.

\section{Empirical Results}

\subsection{Descriptive Analysis}

Panel A of Table 1 shows the descriptive statistics for all of the regression variables in this study. The average and median ETR of the samples are 0.272 and 0.212 , respectively; the average (median) of the related parties' goods (or service) 
Table 1. Descriptive statistics.

\begin{tabular}{|c|c|c|c|c|c|}
\hline \multicolumn{6}{|c|}{ Panel A: Descriptive Statistics of Total Sample $(n=17,157)$} \\
\hline Variables & Mean & Std. & Median & Min & $\operatorname{Max}$ \\
\hline$E T R$ & 0.272 & 0.250 & 0.212 & 0.000 & 1.000 \\
\hline$D Y 09$ & 0.785 & 0.411 & 1.000 & 0.000 & 1.000 \\
\hline OPER & 0.055 & 0.132 & 0.005 & 0.000 & 1.162 \\
\hline$D Y 09 \times O P E R$ & 0.037 & 0.110 & 0.000 & 0.000 & 1.162 \\
\hline$S I Z E$ & 21.732 & 1.174 & 21.596 & 18.833 & 25.582 \\
\hline$R O A$ & 0.049 & 0.059 & 0.045 & -0.289 & 0.266 \\
\hline$L E V$ & 0.063 & 0.091 & 0.017 & 0.000 & 0.456 \\
\hline$P P E$ & 0.238 & 0.166 & 0.206 & 0.002 & 0.752 \\
\hline$T E C H$ & 0.466 & 0.499 & 0.000 & 0.000 & 1.000 \\
\hline$L \_E T R$ & 0.242 & 0.241 & 0.193 & 0.000 & 1.000 \\
\hline \multicolumn{6}{|c|}{$\begin{array}{l}\text { Panel B: Descriptive Statistics related to Pre-Implementation Year } \\
\text { of Measures for Special Tax Adjustment }(n=3691)\end{array}$} \\
\hline Variables & Mean & Std. & Median & Min & $\operatorname{Max}$ \\
\hline$E T R$ & 0.231 & 0.216 & 0.186 & 0.000 & 1.000 \\
\hline OPER & 0.084 & 0.162 & 0.018 & 0.000 & 1.150 \\
\hline$S I Z E$ & 21.353 & 1.040 & 21.267 & 18.837 & 25.528 \\
\hline$R O A$ & 0.042 & 0.064 & 0.039 & -0.285 & 0.265 \\
\hline$L E V$ & 0.066 & 0.089 & 0.027 & 0.000 & 0.455 \\
\hline$P P E$ & 0.302 & 0.176 & 0.281 & 0.002 & 0.752 \\
\hline TECH & 0.380 & 0.486 & 0.000 & 0.000 & 1.000 \\
\hline$L \_E T R$ & 0.192 & 0.185 & 0.160 & 0.000 & 1.000 \\
\hline \multicolumn{6}{|c|}{$\begin{array}{l}\text { Panel C: Descriptive Statistics related to Post-Implementation Year } \\
\text { of Measures for Special Tax Adjustment }(n=13,466)\end{array}$} \\
\hline Variables & Mean & Std. & Median & Min & $\operatorname{Max}$ \\
\hline$E T R$ & 0.284 & 0.258 & 0.219 & 0.000 & 1.000 \\
\hline OPER & 0.048 & 0.122 & 0.004 & 0.000 & 1.162 \\
\hline$S I Z E$ & 21.835 & 1.187 & 21.694 & 18.833 & 25.582 \\
\hline$R O A$ & 0.051 & 0.057 & 0.047 & -0.289 & 0.266 \\
\hline$L E V$ & 0.062 & 0.092 & 0.013 & 0.000 & 0.456 \\
\hline$P P E$ & 0.220 & 0.159 & 0.188 & 0.002 & 0.752 \\
\hline$T E C H$ & 0.490 & 0.500 & 0.000 & 0.000 & 1.000 \\
\hline$L \_E T R$ & 0.256 & 0.252 & 0.199 & 0.000 & 1.000 \\
\hline
\end{tabular}

Note 1: Variable definitions: $E T R$ is the effective tax rate; $D Y 09$ is the dummy variable of Measures for Special Tax Adjustment period; OPER is the related parties' goods (service) transaction ratio; SIZE is the size of enterprise; $R O A$ is the profitability; $L E V$ is the leverage of finance; $P P E$ is the capital intensity; $T E C H$ is the dummy variable of new and high-tech enterprises; $L \_E T R$ is the pre-period effective tax rate. 
transaction ratio $(O P E R)$ is $0.055(0.005)$. Moreover, $78.5 \%$ of the observations are related to the post-implementation year of the Special Tax Adjustment Measures (2009 to 2015).

Panel B and Panel C of Table 1 show the descriptive statistics of variables related to the pre- (2005 to 2008) and post-implementation years of Measures for Special Tax Adjustment (2009 to 2015). Comparing Panel B and Panel C reveals that the average ETR increases by approximately $23 \%$ (from 0.231 to 0.284 ) after the implementation of Measures for Special Tax Adjustment. Thus, the implementation of Measures for Special Tax Adjustment in 2009 effectively curbs corporate tax avoidance behavior, thereby increasing the ETR; this is consistent with H1. Additionally, the average related party goods (or service) transaction ratio (OPER) decreases by approximately $43 \%$ (from 0.084 to 0.048 ) after the implementation of Measures for Special Tax Adjustment, implying that their implementation has a significant effect on related parties' goods (or service) transactions.

Regarding control variables, Panel B and Panel C of Table 1 reveal that the new and high-tech enterprises (TECH) increase significantly after the implementation of Measures for Special Tax Adjustment. The possible reason is that the implementation of Measures for Special Tax Adjustment increases the risk of corporate tax avoidance. New and high-tech enterprises can apply for the preferential corporate income tax rate of $15 \%$; therefore, enterprises increasingly apply for the certificate of new and high-tech enterprises to reduce their tax burden legally.

Table 2 provides Spearman (above the diagonal) and Pearson (below the diagonal) correlations among the variables. This table shows that for Measures for Special Tax Adjustment implementation period (DY09) and the interaction terms of $D Y 09 \times O P E R$ are significantly and positively associated with the ETR;

Table 2. Spearman and pearson correlations.

\begin{tabular}{|c|c|c|c|c|c|c|c|c|c|c|}
\hline Variables & $E T R$ & DYO9 & OPER & $D Y 09 \times O P E R$ & $S I Z E$ & $R O A$ & $L E V$ & $P P E$ & $T E C H$ & $L \_E T R$ \\
\hline ETR & 1 & $0.070^{* * *}$ & $0.036^{* * *}$ & $0.083^{* * *}$ & $0.122^{\star \star *}$ & -0.000 & $0.057^{\star \star \star}$ & $-0.048^{\star * *}$ & -0.011 & $0.471^{\star * *}$ \\
\hline OPER & $0.030^{* * *}$ & $-0.110^{* * *}$ & 1 & $0.638^{* * *}$ & $0.266^{* * *}$ & $-0.085^{\star * *}$ & $0.160^{* * *}$ & $0.223^{\star * *}$ & $-0.039^{* * *}$ & $0.078^{* * *}$ \\
\hline$D Y 09 \times O P E R$ & $0.048^{\star * *}$ & $0.195^{\star * *}$ & $0.752^{* * *}$ & 1 & $0.323^{\star * *}$ & $-0.042^{\star \star \star}$ & $0.114^{\star * *}$ & $0.056^{\star * *}$ & -0.003 & $0.113^{\star * *}$ \\
\hline$S I Z E$ & $0.084^{\star * *}$ & $0.150^{\star * *}$ & $0.155^{\star * *}$ & $0.183^{\star * *}$ & 1 & $-0.015^{\star \star}$ & $0.477^{\star * *}$ & $0.029^{\star * *}$ & $-0.123^{\star * \star}$ & $0.198^{\star * *}$ \\
\hline$R O A$ & $-0.054^{* * *}$ & $0.076^{* * *}$ & $-0.030^{* * *}$ & $-0.031^{\star *}$ & $0.023^{* * *}$ & 1 & $-0.207^{\star \star *}$ & $-0.164^{\star * *}$ & $0.099^{* * *}$ & $-0.113^{* * *}$ \\
\hline$L E V$ & $0.037^{\star * *}$ & $-0.015^{\star *}$ & $0.025^{\star * *}$ & $0.032^{\star * *}$ & $0.446^{* * *}$ & $-0.139^{\star * *}$ & 1 & $0.218^{\star * *}$ & $-0.172^{\star * *}$ & $0.119^{* * *}$ \\
\hline$P P E$ & $-0.020^{* * *}$ & $-0.188^{\star \star \star}$ & $0.129^{* * *}$ & $0.064^{\star * *}$ & $0.064^{* * *}$ & $-0.161^{\star * *}$ & $0.240^{* * *}$ & 1 & $-0.035^{\star * *}$ & $0.014^{\star *}$ \\
\hline$L \_E T R$ & $0.347^{* * *}$ & $0.072^{* * *}$ & $0.037^{* * *}$ & $0.072^{* * *}$ & $0.126^{* * *}$ & $-0.165^{\star * *}$ & $0.066^{* * *}$ & 0.011 & $-0.028^{* * *}$ & 1 \\
\hline
\end{tabular}

Note 1: All variables are defined in note 1 of Table 1 . Note $2:{ }^{* *},{ }^{* *}$ and ${ }^{*}$ denote significant at the $1 \%, 5 \%$ and $10 \%$ (two-side level), respectively. Note 3 : Contemporaneous Spearman (Pearson) correlations on the Upper (lower) diagonal. 
this is consistent with our expectations. All of the correlation coefficients in Table 2 range from -0.207 to 0.752 , there is no liner multicollinearity problem.

\subsection{Regression Analysis}

Table 3 presents the results from the regression of Equation (1). Table 3 shows that the DY09 coefficient is significant and positive (t statistic = 4.53): $\mathrm{H} 1$ is thus supported. This implies the effectiveness of the implementation of Measures for Special Tax Adjustment.

Moreover, the coefficient on the interaction term DY09 $\times$ OPER is $0.048(\mathrm{t}$ statistic $=2.11)$, and it is significantly and positively associated with the ETR. This reveals that the Chinese SAT has issued many TP related regulations and rules since 2009; therefore, companies with more related parties' goods (or service) transactions increase their ETRs more than their counterparts after the implementation of Measures for Special Tax Adjustment; $\mathrm{H} 2$ is thus supported.

Regarding the regression results of control variables, the coefficient on the term SIZE is significantly positive, which is consistent with the political cost hypothesis. This means that large companies often face greater monitoring from the public and government; therefore, their political costs are higher than those of other companies (Zimmerman, 1983). The significant and negative coefficients of capital intensity (PPE) are consistent with our expectation, implying that depreciation expenses can act as tax shields and reduce the corporate tax burden (Gupta \& Newberry, 1997). The negative association between TECH and $E T R$ implies that new and high-tech enterprises can apply for the preferential

Table 3. Regression results.

\begin{tabular}{|c|c|c|c|c|}
\hline \multicolumn{4}{|c|}{$\begin{aligned} E T R_{i, t}= & \alpha_{0}+\alpha_{1} D Y 09_{i, t}+\alpha_{2} D Y 09_{i, t} \times O P E R_{i t,}+\alpha_{3} \operatorname{SIZE}_{i, t}+\alpha_{4} R O A_{i, t} \\
& +\alpha_{5} L E V_{i, t}+\alpha_{6} P P E_{i, t}+\alpha_{7} T E C H_{i, t}+\alpha_{8} L \_E T R_{i, t}+\varepsilon_{i, t}\end{aligned}$} & \multirow{2}{*}{$\begin{array}{c}\text { (1) } \\
p \text {-value }\end{array}$} \\
\hline Variables & Pred. Sign & Coefficient & t-stat. & \\
\hline Intercept & & 0.003 & 0.05 & 0.9580 \\
\hline$D Y 09$ & + & 0.028 & $4.53^{* * *}$ & $<0.001$ \\
\hline$D Y 09 \times O P E R$ & + & 0.048 & $2.11^{* *}$ & 0.0348 \\
\hline SIZE & \pm & 0.008 & $3.36^{* * *}$ & 0.0008 \\
\hline$R O A$ & \pm & -0.038 & -0.90 & 0.3686 \\
\hline$L E V$ & - & 0.024 & 0.76 & 0.4481 \\
\hline$P P E$ & - & -0.039 & $-2.55^{\star *}$ & 0.0106 \\
\hline TECH & - & -0.014 & $-2.82^{\star * *}$ & 0.0049 \\
\hline$L_{-} E T R$ & + & 0.405 & $47.45^{* * *}$ & $<0.001$ \\
\hline Adj R-squared & \multicolumn{4}{|c|}{0.1339} \\
\hline F-value & \multicolumn{4}{|c|}{$326.70(p$-value $<0.0001)$} \\
\hline $\mathrm{n}$ & \multicolumn{4}{|c|}{16,848} \\
\hline
\end{tabular}

Note 1: All variables are defined in note 1 of Table 1 . Note $2:{ }^{* *},{ }^{* *}$ and ${ }^{*}$ denote significant at the $1 \%, 5 \%$ and $10 \%$ (two-side level), respectively. 
corporate income tax rate of $15 \%$; hence, they have a lower tax burden compared with other industries. The positive coefficient of the pre-period ETR ( $L E E T R)$ implies that firms with a higher pre-period ETR will also have a higher current ETR. However, the coefficient on the profitability $(R O A)$ term is nonsignificant.

\section{Conclusion}

This study uses the Shanghai and Shenzhen A-share listed companies from 2005 to 2015 to investigate whether the implementation of Measures for Special Tax Adjustment in 2009 has effectively enhanced corporate ETRs. The empirical results indicate that companies' ETRs increase significantly after the implementation of Measures for Special Tax Adjustment, revealing the effectiveness of this policy. In addition, the results reveal that the ETRs of companies with greater amounts of related party transactions of goods (or services) increase significantly after the implementation of Measures for Special Tax Adjustment. This result implies that the implementation of Measures for Special Tax Adjustment can curb corporate tax planning with TP, thus ensuring tax revenue for the country.

During periods of economic decline, to avoid the erosion of tax revenue, countries around the world have established relevant regulations to regulate corporate tax avoidance. As tax authorities become more protective of tax revenues, international tax planning comes under increased scrutiny, and businesses with noncompliant tax avoidance practices are much more likely to receive tax penalties and significant interference from regulatory authorities. Hence, companies must pay strict attention to ensure that their international transactions are compliant with anti-avoidance guidelines and must review their organizational structures, trading patterns, and daily operations of the overseas subsidiaries as soon as possible to mitigate unintended tax exposures.

This study has some limitations and suggestions in the future. Firstly, the research period is 2005 to 2015 due to the database purchased. Secondly, to sound anti-tax avoidance actions in line with the BEPS structure, in addition to promulgate the Measures for Special Tax Adjustment in 2009, the Chinese SAT issued a public notice regarding the release of the "Administrative Measures for Special Tax Investigation Adjustment and Mutual Agreement Procedures" (SAT Public Notice [2017] No.6, hereinafter referred to as "Public Notice 6") in 2017, which went into effect on May 1, 2017. Public Notice 6 highlights the tax authorities' emphasis on strengthening the monitoring of enterprises' profit levels and improving enterprises' compliance with the tax law. Furthermore, Public Notice 6 reinforces the regulation of TP administration on intercompany intangibles and service transactions. Therefore, in formulating the relevant TP strategies, the group should pay close attention to the requirements stated in Public Notice 6 to ensure that their tax planning is in compliance with the laws.

\section{Conflicts of Interest}

The authors declare no conflicts of interest regarding the publication of this paper. 


\section{References}

Bartelsman, E. J., \& Beetsma, R. M. (2003). Why Pay More? Corporate Tax Avoidance through Transfer Pricing in OECD Countries. Journal of Public Economics, 87, 2225-2252. https://doi.org/10.1016/S0047-2727(02)00018-X

Bernard, A. B., Jensen, J. B., \& Schott, P. K. (2009). Importers, Exporters, and Multinationals: A Portrait of Firms in the U.S. That Trade Goods. In Producer Dynamics: New Evidence from Micro Data (pp. 513-552). Chicago, IL: University of Chicago Press. https://doi.org/10.7208/chicago/9780226172576.003.0015

Chen, M. C. (2003). The Effect of Tax Incentives on Tax Burden of Profit-Seeking Enterprises. Management Review, 22, 127-151. (In Chinese)

Chen, M. C., Lin, S. M., \& Chang, T. H. (2001). The Impact of Tax-Exempt Stock and Land Capital Gains on Corporate Effective Tax Rates. Taiwan Accounting Review, 2, 33-56.

Clausing, K. A. (2003). Tax-Motivated Transfer Pricing and US Intrafirm Trade Prices. Journal of Public Economics, 87, 2207-2223. https://doi.org/10.1016/S0047-2727(02)00015-4

Clausing, K. A. (2006). International Tax Avoidance and U.S. International Trade. National Tax Journal, 59, 269-287. https://doi.org/10.17310/ntj.2006.2.05

Desai, M., \& Dharmapala, A. D. (2006). Corporate Tax Avoidance and High-Powered Incentives. Journal of Financial Economics, 79, 145-179.

https://doi.org/10.1016/j.jfineco.2005.02.002

Document No. 2 (2009). Implementing Measures for Special Tax Adjustment (Trial). No. 2. State Administration of Taxation.

Graham, J. R. (2000). How Big Are the Tax Benefits of Debt? The Journal of Finance, 55, 1901-1941. https://doi.org/10.1111/0022-1082.00277

Gramlich, J. D., \& Wheeler, J. E. (2003). How Chevron, Texaco and Indonesian Government Structured Transactions to Avoid Billions in US Income Taxes. Accounting Horizons, 17, 107-122. https://doi.org/10.2308/acch.2003.17.2.107

Gupta, S., \& Newberry, K. (1997). Determinants of the Variability Incorporate Effective Tax Rates: Evidence from Longitudinal Data. Journal of Accounting and Public Policy, 16, 1-34. https://doi.org/10.1016/S0278-4254(96)00055-5

Jacob, J. (1996). Taxes and Transfer Pricing: Income Shifting and the Volume of Intra-Firm Transfers. Journal of Accounting Research, 34, 301-312. https://doi.org/10.2307/2491504

Liu, A. M., \& Liu, D. R. (2011). Empirical Study of Special Tax Adjustment of Enterprise Income on Tax Anti-Avoidance Effect. System Engineering, 29, 106-110. (In Chinese)

Liu, C. C., Lin, S., \& Huang, D. F. (2001). Factors Influencing Corporate Effective Tax Rates in Taiwan. Taiwan Accounting Review, 2, 57-84.

Mills, L., Erickson, M. M., \& Maydew, E. L. (1998). Investments in Tax Planning. The Journal of the American Taxation Association, 20, 1-20. https://doi.org/10.2308/jata.2001.23.1.1

Olibe, K. O., \& Rezaee, Z. (2008). Income Shifting and Corporate Taxation: The Role of Cross-Border Intrafirm Transfers. Review of Accounting and Finance, 7, 83-101. https://doi.org/10.1108/14757700810853860

Oyelere, P. B., \& Emmanuel, C. R. (1998). International Transfer Pricing and Income-Shifting: Evidence from the UK. The European Accounting Review, 7, 623-635. https://doi.org/10.1080/096381898336222 
Park, S. J., Park, W. J., Sun, E. J., \& Woo, S. (2016). Is Foreign Direct Investment Effective from the Perspective of Tax Avoidance? An Analysis of Tax Avoidance through the International Transfer Pricing Behaviors of Korean Corporations. Journal of Applied Business Research, 32, 917-934. https://doi.org/10.19030/jabr.v32i3.9664

Porcano, T. (1986). Corporate Tax Rates: Progressive, Proportional, or Regressive. The Journal of the American Taxation Association, 7, 17-31.

Rego, S. (2003). Tax-Avoidance Activities of U.S. Multinational Corporations. Contemporary Accounting Research, 20, 805-833. https://doi.org/10.1506/VANN-B7UB-GMFA-9E6W

Siegfried, J. (1974). Effective Average U.S. Corporation Income Tax Rates. National Tax Journal, 27, 245-259.

Stickney, C. P., \& McGee, V. E. (1982). Effective Corporate Tax Rates: The Effect of Size, Capital Intensity, Leverage, and Other Factors. Journal of Accounting and Public Policy, 1, 125-152. https://doi.org/10.1016/S0278-4254(82)80004-5

Tang, X. G., Shen, J. L., Chen, M. C., \& Wang, J. C. (2017). Related-Party Transaction, Thin-Capitalization and Tax-Avoidance Policy. Taxation Research, 387, 82-85. (In Chinese)

Zimmerman, J. (1983). Taxes and Firm Size. Journal of Accounting and Economics, 5, 119-149. https://doi.org/10.1016/0165-4101(83)90008-3 